\title{
Microcharon quilli, a new asellote isopod crustacean from interstitial spaces in shallow coralline sands off St. Eustatius, Caribbean Netherlands
}

\author{
Ronald Vonk ${ }^{1,2}$ (1) Yee Wah Lau ${ }^{1,3}$
}

Received: 4 July 2016 /Revised: 26 September 2016 / Accepted: 27 September 2016 / Published online: 20 October 2016

(C) The Author(s) 2016. This article is published with open access at Springerlink.com

\begin{abstract}
The genus Microcharon is known in the Caribbean from the widely separated islands of Bonaire and Cuba, occurring in brackish and freshwater subterranean environments. Here we describe a new species from reef sands off St. Eustatius, eastern Caribbean. Morphological differences are small between the eleven other marine or coastal groundwater Microcharon species that are known worldwide, and comparisons do not show a biogeographic pattern of sequential dispersion.
\end{abstract}

Keywords Crustaceans $\cdot$ Lepidocharontidae $\cdot$ Marine interstitial $\cdot$ Meiofauna $\cdot$ Systematics

\section{Introduction}

Lepidocharontid isopods have their largest radiation in the genus Microcharon with at least 70 species (Schotte 2007;

\section{Communicated by B. W. Hoeksema}

This article is registered in ZooBank under urn:1sid:zoobank. org:pub:F0BBBCFE-AD10-4E13-9BDB-984FB8B6E8F1

Nomenclatural acts herein are registered as follows: Species Microcharon quilli urn:1sid:zoobank.org:act:58F78412-0A08-4716-9970B3EC1ECDB5AA

Ronald Vonk

ronald.vonk@naturalis.nl

1 Naturalis Biodiversity Center, P.O. Box 9517, 2300

RA Leiden, The Netherlands

2 Institute for Biodiversity and Ecosystem Dynamics, University of Amsterdam, 1098 XH Amsterdam, The Netherlands

3 Institute of Biology Leiden, Leiden University, P.O. Box 9505, 2300 RA Leiden, The Netherlands
Coineau et al. 2013; Galassi et al. 2016), of which just a small part is marine (Coineau 1986). Most species of Microcharon are known from fresh groundwater habitats in countries around the Mediterranean, probably because of a long history of sampling efforts there by numerous zoologists. The marine species are found in shallow sandy bottoms, but no records are known from dredging samples of deeper seafloor sediment. The marine species are further known from intertidal and sandy beaches in the Caribbean, Mediterranean, Brittany (France), English Channel, Galapagos, and New Caledonia (Coineau et al. 2013; Albuquerque et al. 2014; Galassi et al. 2016).

Here we present the description of a new species of Microcharon, resulting from a 3-week sampling expedition at the leeward side of the volcanic island of St. Eustatius (Hoeksema 2016). Microcharon quilli $\mathrm{n}$. sp. is described from six places in coralline white sands between submerged lava outcrops in Oranjestad Bay and Jenkins Bay (Fig. 1b).

\section{Materials and methods}

The 73 specimens of the new species were collected from several sites by means of scuba diving at depths between 2 and $25 \mathrm{~m}$. Samples were collected by hand-pushing plastic probing tubes of $12 \mathrm{~cm}$ length and $2.5 \mathrm{~cm}$ diameter into the sand at selected places. Stations of these dive localities (with EUX numbers) are indicated by Hoeksema (2016). At each sampling site, the top layer of coarse reef sand was thick enough, allowing vertical to slightly skewed probing. The top of the tube contained a small hole for the escape of excess water. After closing the top, which creates a vacuum preventing the sediment from spilling, the tube was carefully removed and quickly shut at the opening (Fig. 1c). The samples were sorted in the laboratory of CNSI (Caribbean Netherlands Science Institute; Oranjestad, St. Eustatius) under a 
Fig. 1 a Microcharon quilli $n$. sp. paratype, RMNH.CRUS.7718, female $1.5 \mathrm{~mm}$, carrying eggs. Antennae and uropods broken off. b Map of St. Eustatius with offshore sampling sites. c Sampling method, filling tubes with sediment at selected sites (photo A. Speksnijder)

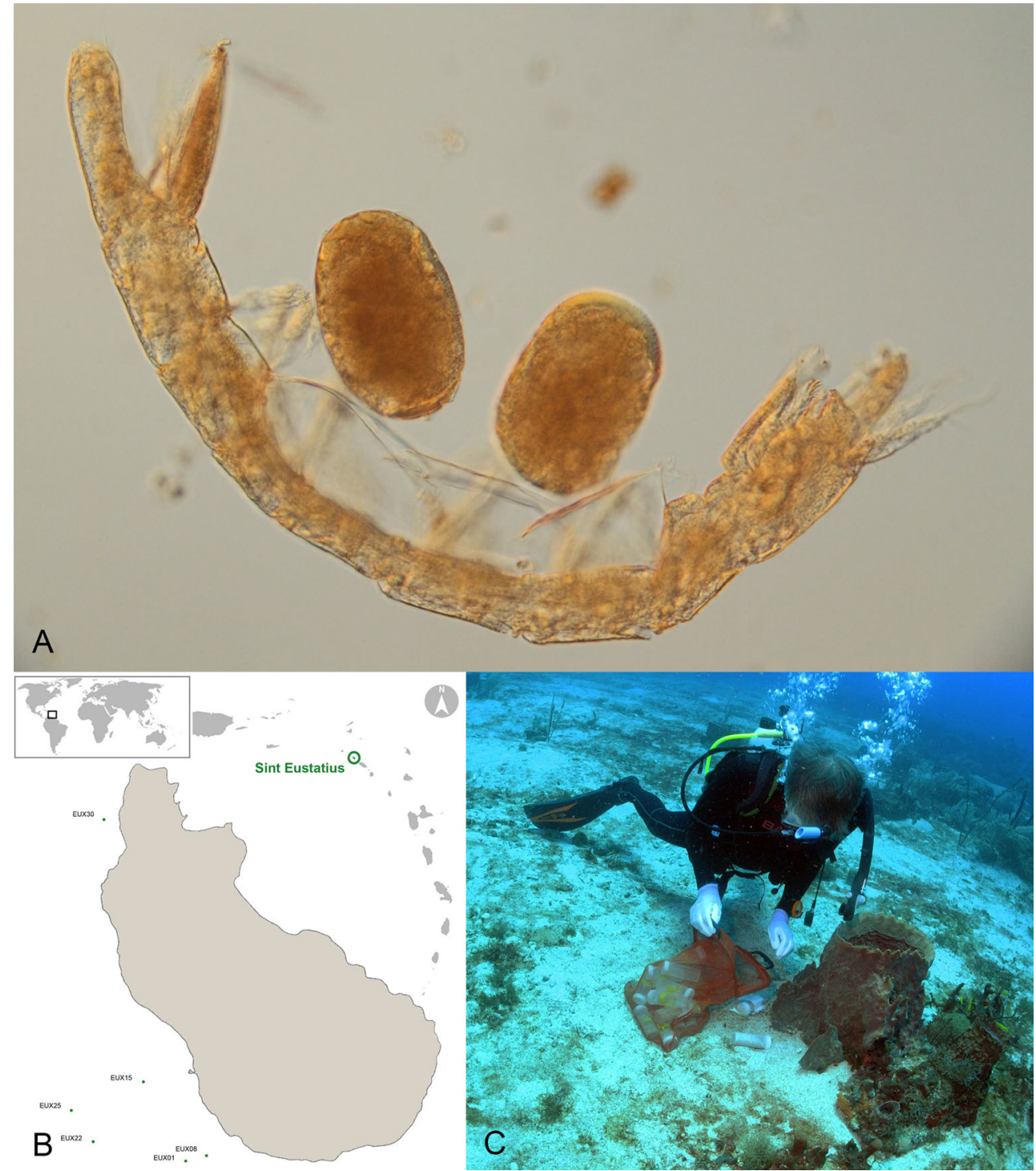

dissecting microscope and transferred to $96 \%$ ethanol. Before dissection, specimens were treated with lactic acid to soften the cuticle and remove internal tissues to facilitate observation. Drawings were prepared using a camera lucida on an Olympus BX 53 microscope equipped with differential interference contrast (DIC). Specimens and appendages preserved on slides were mounted in Faure's medium and the coverslips sealed with transparent nail varnish. Specimens have been deposited in the Crustacea collection of Naturalis Biodiversity Center in Leiden with catalogue numbers RMNH.CRUS.

\section{Taxonomy}

Order Isopoda Latreille, 1817

Suborder Asellota Latreille, 1803

Superfamily Janiroidea Sars, 1897
Family Lepidocharontidae Galassi and Bruce, 2016 Microcharon quilli sp. nov.

urn:lsid:zoobank.org:act: 58F78412-0A08-4716-9970B3EC1ECDB5AA

(Figs. 1,2,3,4 and 5)

\section{Material examined}

Collected by R. Vonk, June 2015, off the sheltered west coast of the island of St. Eustatius, Caribbean Netherlands with the following catalogue numbers and dive sites: RMNH.CRUS.I.7712 (15 specimens) at EUX 01, Princess Bay, $17^{\circ} 27.82^{\prime} \mathrm{N}, 062^{\circ} 59.209^{\prime}$ W, $18 \mathrm{~m}$ depth; RMNH.CRUS.I.7713 (11 specimens) at EUX 08, Five Fingers North, $17^{\circ} 27.893^{\prime} \mathrm{N}$, $062^{\circ} 59.007^{\prime} \mathrm{W}, 18 \mathrm{~m}$ depth; RMNH.CRUS.I.7714 (22 specimens) at EUX 15, Blue Bead Hole, 

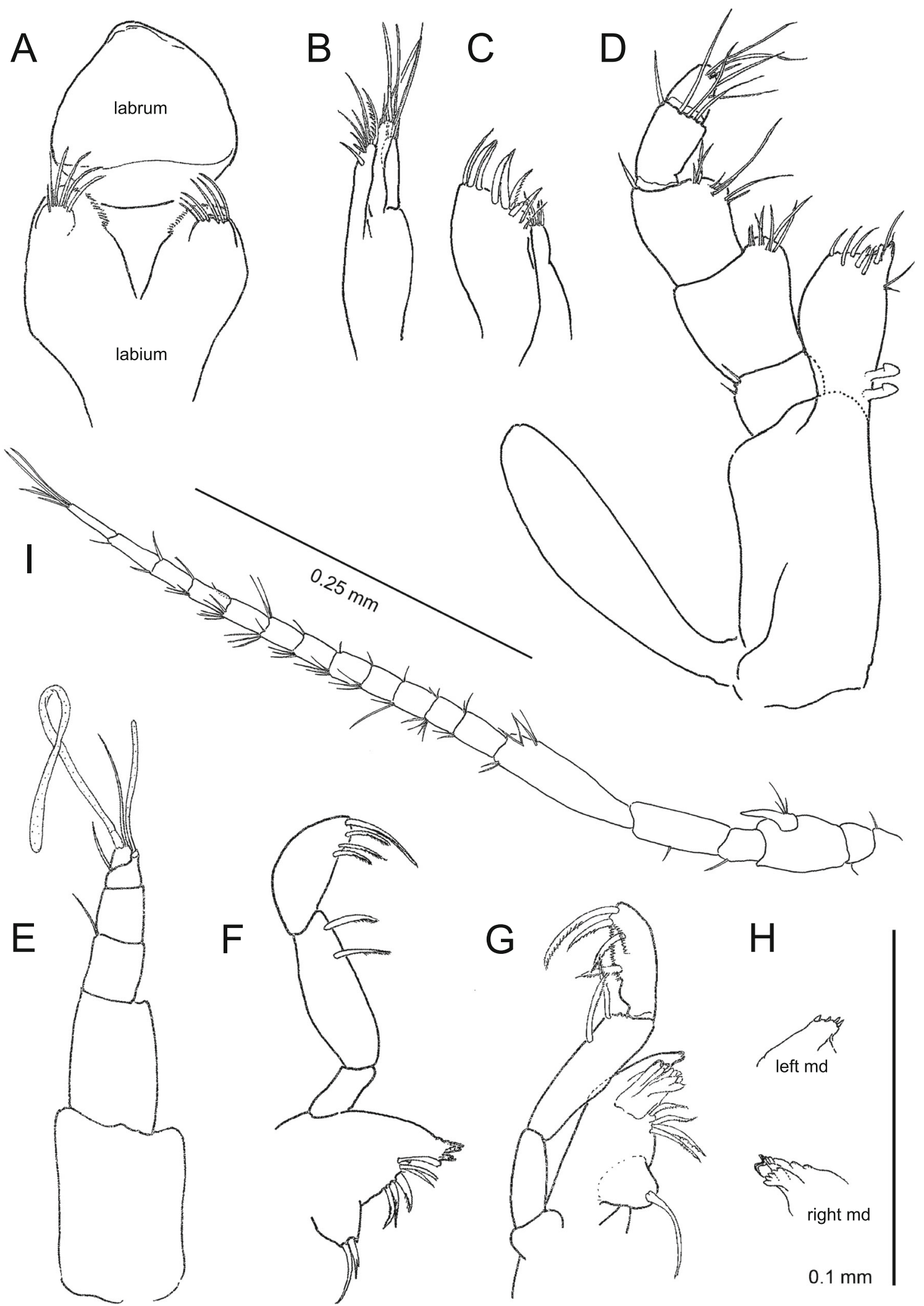

Fig. 2 Microcharon quilli n. sp. holotype, RMNH.CRUS.21509, male $1.5 \mathrm{~mm}$ : a Paragnaths, upper and lower lip. b Maxilla. c Maxillule. d Maxilliped. e Antennule. f Right mandible and palp. g Left mandible and

palp. h Paratype, RMNH.CRUS.21511, female $1.0 \mathrm{~mm}$, Left and right mandibles. i Holotype, antenna. a-h Scale bar: $0.1 \mathrm{~mm}$; i adjacent scale bar: $0.25 \mathrm{~mm}$ 

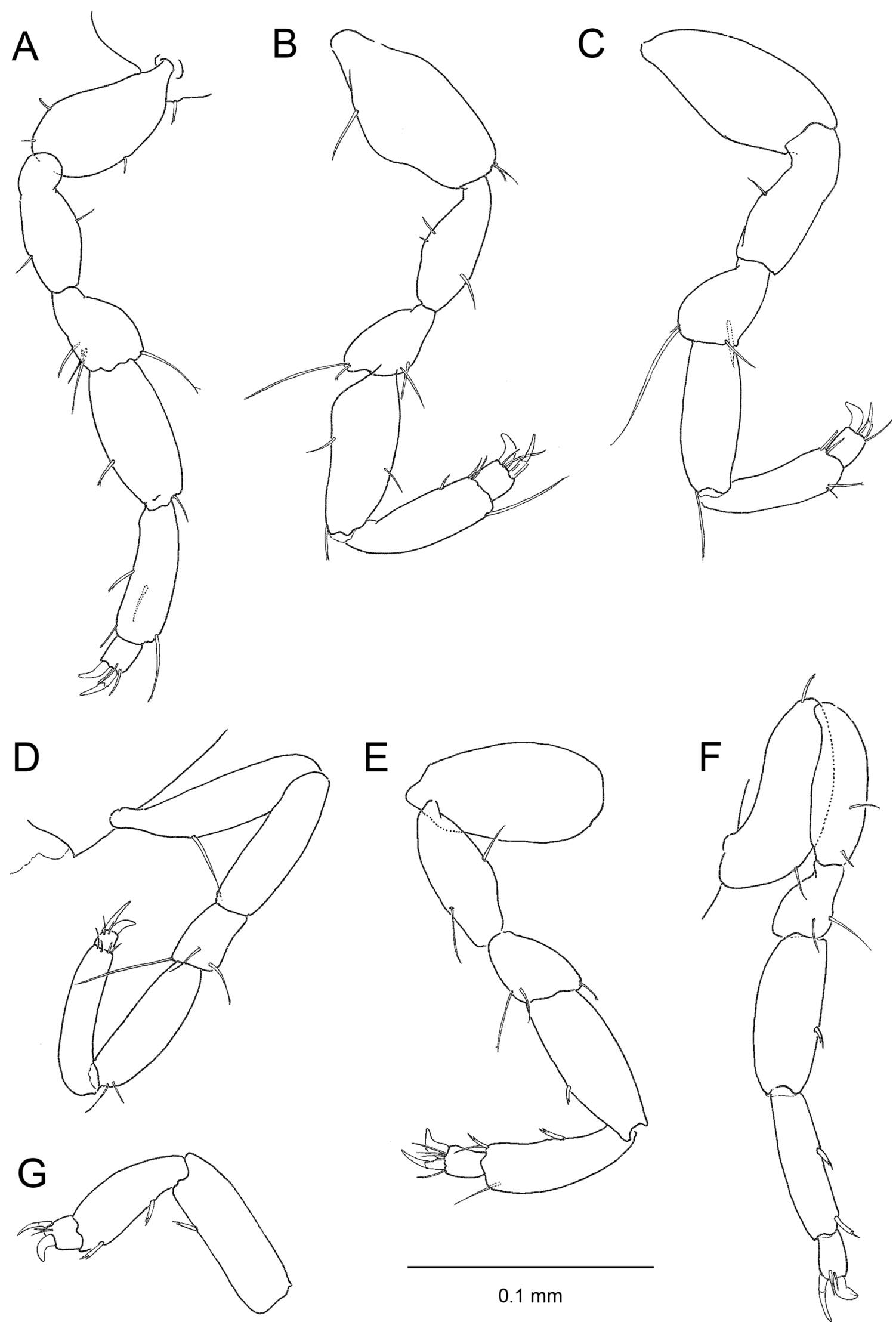

Fig. 3 Microcharon quillin. sp. holotype, RMNH.CRUS.21509, male $1.5 \mathrm{~mm}$. a Pereiopod 1. b Pereiopod 2. c Pereiopod 3. d Pereiopod 4. e Pereiopod 5. f Pereiopod 6. g Pereiopod 7, distal segments. a-g Scale bar: $0.1 \mathrm{~mm}$ 

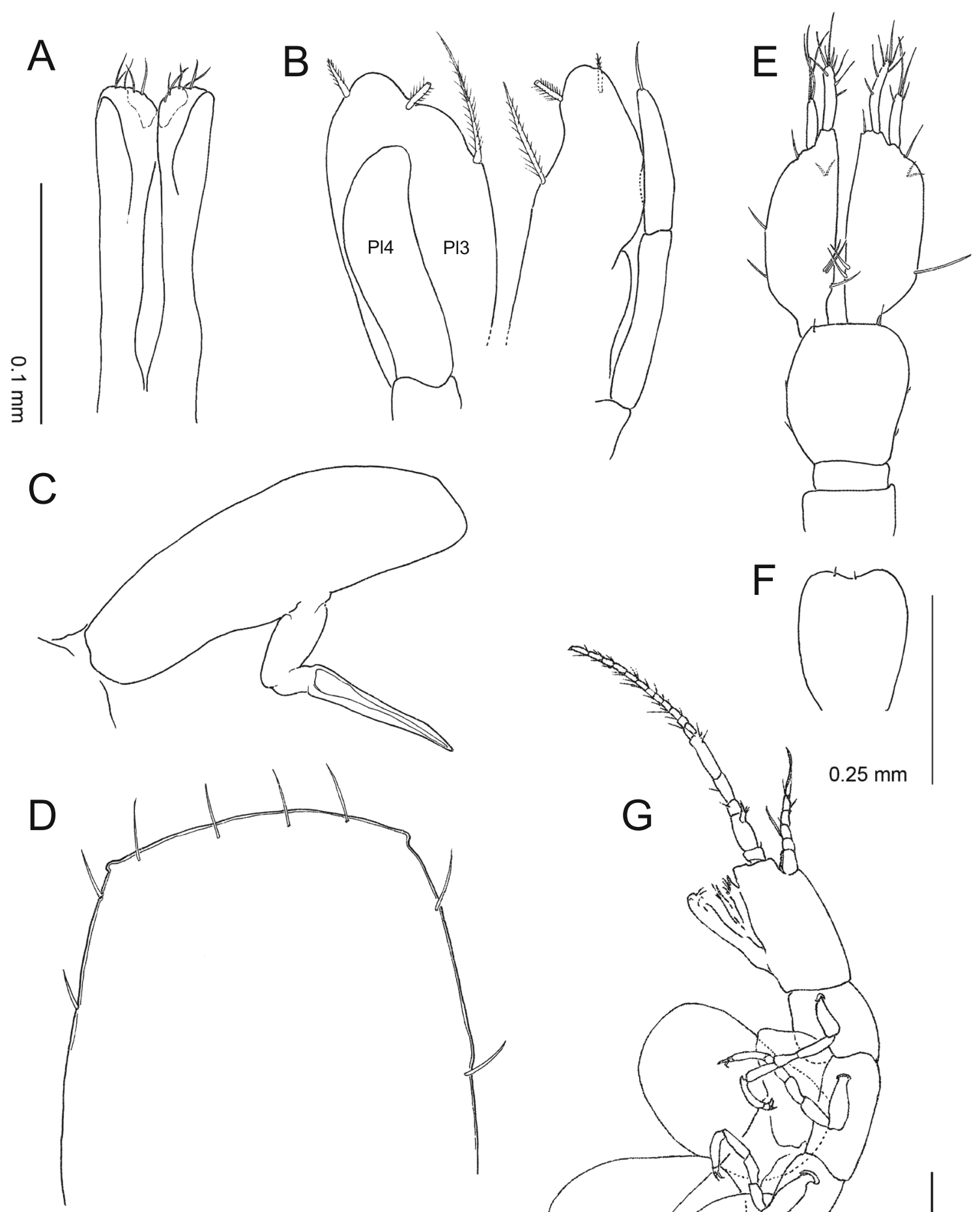


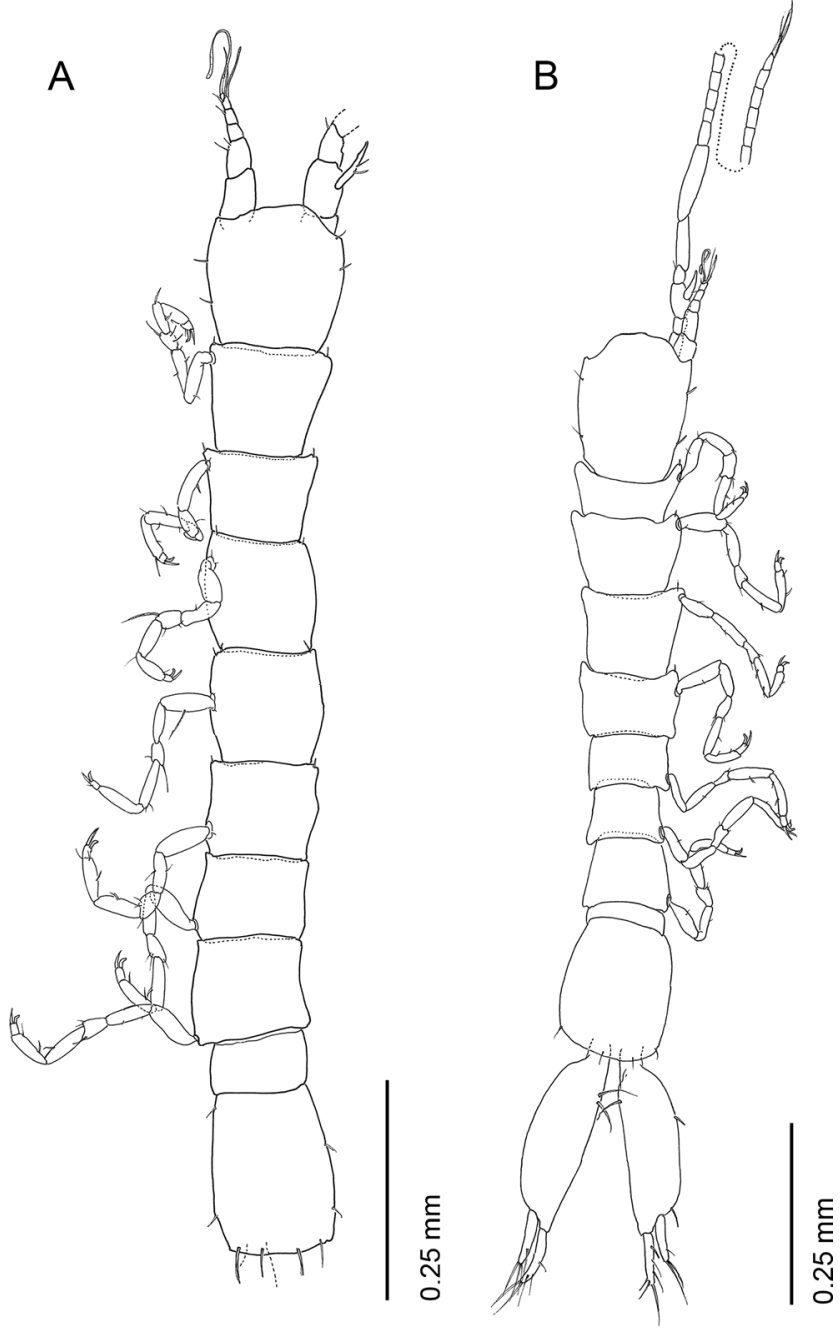

Fig. 5 Microcharon quilli n. sp. a Paratype, RMNH.CRUS.21510, male $1.1 \mathrm{~mm}$. b Paratype, RMNH.CRUS.21511, female $1.0 \mathrm{~mm}$. Appendages pictured on one side only

$17^{\circ} 28.550^{\prime} \mathrm{N}, 062^{\circ} 59.670^{\prime} \mathrm{W}, 17 \mathrm{~m}$ depth; RMNH.CRUS.I.7715 (one specimen) at EUX 22, Maxima's Reef, $17^{\circ} 27.960^{\prime} \mathrm{N}, 063^{\circ} 00.125^{\prime} \mathrm{W}, 23 \mathrm{~m}$ depth; RMNH.CRUS.I.7716 at EUX 25 (19 specimens), Lost Anchors, $17^{\circ} 28.250^{\prime} \mathrm{N}, 063^{\circ} 00.370^{\prime} \mathrm{W}$, $22 \mathrm{~m}$ depth; RMNH.CRUS.I.7717 (one specimen) at EUX 30, Twin Sisters, $17^{\circ} 30.993^{\prime} \mathrm{N}, 063^{\circ} 00.180^{\prime} \mathrm{W}$, $16 \mathrm{~m}$ depth.

Holotype, RMNH.CRUS.21509, male, 1.5 mm, EUX 08, Five Fingers North, $17^{\circ} 27.893^{\prime} \mathrm{N}, 062^{\circ} 59.007^{\prime} \mathrm{W}, 18 \mathrm{~m}$ depth. Paratypes, RMNH.CRUS.21510, male, $1.1 \mathrm{~mm}$, EUX 08, Five Fingers North, $17^{\circ} 27.893^{\prime} \mathrm{N}, 062^{\circ} 59.007^{\prime} \mathrm{W}, 18 \mathrm{~m}$ depth; RMNH.CRUS.21511, female $1.0 \mathrm{~mm}$, EUX 25, Lost Anchors, $17^{\circ} 28.250^{\prime} \mathrm{N}, 063^{\circ} 00.370^{\prime} \mathrm{W}, 22 \mathrm{~m}$ depth; RMNH.CRUS.I. 7718, female with 2 eggs, $1.5 \mathrm{~mm}$, EUX 25 , Lost Anchors, $17^{\circ} 28.250^{\prime} \mathrm{N}, 063^{\circ} 00.370^{\prime} \mathrm{W}, 22 \mathrm{~m}$ depth.

\section{Diagnosis}

Body length up to $1.5 \mathrm{~mm}$. Cephalosome is longer than wide, rostrum absent; eyes absent; pedigerous somites longer than wide, somites $2-5$ in ovigerous female flattened dorsoventrally with large oostegites (Fig. 1a); uropod with large and broad protopod; antennule with six segments; antenna with 12 flagellum segments and six podomeres; maxilla endite with one robust seta with spinules; maxilliped with large coupling hooks; inner claws of pereiopods strongly bent and thick; carpus of all pereipods slightly inflated; carpus of P5-P7 with one robust 'clothespin' seta on inner margin, propodus with two such setae on inner margin; pleopod 3 exopod slender; uropod peduncle curved inwards at basolateral margin, giving it a stalked appearance; pleotelson with pointed corners on posterior margin in male.

\section{Etymology}

Species named after the dormant volcano "The Quill" which dominates the landscape of St. Eustatius, above and under water. The volcano has formed diagonal lava 'fingers' with coarse sand in between, well aerated and silt free because of current and wave action. This creates favorable conditions for sand inhabitants such as Microcharon species.

Distribution Known thus far only from the type locality in the shallow marine sands on the leeward side of the island of St. Eustatius.

\section{Description}

Body length (without antennae and uropods) $1.0-1.5 \mathrm{~mm}$ (Fig. 5a, b). Head longer than wide, without a rostrum but with a slightly protruding margin on the frontal side.

Antennule (Fig. 2e) six-segmented, last segment very small. Segment 5 and 6 bear aesthetascs on distal margin; setae seem to be not plumose and are absent on several segments. In male paratype (Fig. 5a), two small setae are present on the second segment.

Antenna (Fig. 2i) with a pointed, one-segmented exopodite, armed with two or three setae. The flagellum counts 12 segments.

Mandibles (Fig. 2f-h). The left mandible (Fig. 2g) has a lacinia mobilis with a forked process on its inner side; four setae on lateral margin between lacinia and molar process. Molar process is a rounded protuberance with one robust seta; palp with two pinnate setae on inner margin of segment 2 , and three pinnate seta on finely serrated inner margin of segment 3. Incisor in female lined with four separate teeth (Fig. 2h). Right mandible (Fig. 2f) without lacinia mobilis and with three thin setae and three robust spinulose and bended setae; molar process with two setae; palps as in left mandible. 
Paragnaths (Fig. 2a) with six setae on each lobe, planted on a slight protruding fold, inner margin of lobes with fine hairs; labrum rounded and subtriangular.

Maxillula (Fig. 2c) with inner lobe slender, bearing four setae. Outer lobe broad with seven robust setae of which one strongly spinose, and two smaller setae on inner margin.

Maxilla (Fig. 2b) bears three lobes of approximately the same length, inner lobe with oxxne robust spinose comb-like seta, other setae thinner and irregularly placed and of variable length.

Maxilliped (Fig. 2d) with a long, club-like unarmed epipodite. The basipodal endite is distally armed with three larger and three smaller spines, and one longer seta at the inner corner of the endite, this corner hardened and strongly produced; endite mediobasally provided with two exceptionally large coupling hooks. The palp consists of five segments, of which articles 2 and 3 are mesially broad, whereas articles 4 and 5 are narrow and rectangular.

Pereiopods (Fig. 3a-g) biunguiculate, with mostly inflated carpi and strong, broad and sharply curved inner claws on dactyli. Outward claw slender and consisting of two parts or coming from a sheath. P5-P7 have regularly placed forked setae ('clothespin' spines): one on inner margin of the carpus, two on inner margin propodus. Coxal plates minute, of irregular form.

Pleopods. First pleopod in male (Fig. 4a) with five thin seta at apical margin; outer margins at top folded inwards. First pleopod not present in female. Second pleopod (Fig. 4c) of the male suboval, with folded endopodite, distal part filiform, exopodite not discernable; female second pleopod (Fig. 4f) has a subrectangular rounded shape with the medial margin curved inwards, armed with two small setae. Third pleopod not sexually dimorph (Fig. 4b), the exopodite is long and slender, with distal segment bearing one seta; endopodite with three robust spinose setae of which one long and on subapical margin. Fourth pleopod (Fig. 4b) similar in both sexes and consists of a one-segmented unarmed rudimental cone.

Uropod (Fig. 4e) with a shortly stalked, and then a very long and wide, peduncle, longer than pleotelson. Peduncle with two or three setae on basomesial margin. The exopodite is narrow and armed with two or three long terminal setae and two subapical shorter setae. Endopodite longer than exopodite with three subapical setae on inner margin and three on the apex.

Pleotelson (Fig. 4d) in male not rounded at its posterodistal margin but with inconspicuous, pointed corners, and eight marginal and apical setae present.

\section{Remarks}

A comparison with the other three Microcharon species from the Caribbean leads to the following observations.
Microcharon quilli differs from M. herrerai Stock, 1977 (living in a brackish well on Bonaire) in having an antennal flagellum consisting of 12 segments against nine in $M$. herrerai; having one simple robust seta on the molar process of the left mandible instead of two; inner claws on pereiopods plump and robust, fine serrations not present on carpus P4 and P5, setules lacking on medial margin of propodus $\mathrm{P} 1$ and $\mathrm{P} 2$; female operculum with two setae versus four; with a stalked peduncle on uropod and peduncle significantly longer than pleotelson.

From M. phreaticus Coineau and Botosaneanu, 1973 (living in freshwater riverbed interstitial and coastal plain dug wells in Cuba) by having a six-segmented antennule versus five; having an oblong tip on the inner lobe of the maxillule instead of a pointed one; having stout inner claws on the pereiopods versus feeble ones.

From M. sabulum Kensley, 1984 (living in coarse calcareous intertidal sand of Carrie Bow Cay, Belize) by lacking a rostrum; by having a six-segmented antennule versus five; in having an antennal flagellum consisting of 12 segments against eight; in having stout inner claws on the pereiopods versus slender ones; by having a narrow first segment of pleopod 3 versus a broad one; by having the uropod peduncle longer than the pleotelson versus of equal length.

Other marine species outside the Caribbean were collected at the Galapagos, New Caledonia, the British Channel, Portugal, Southern France, and Brittany (France). Microcharon quilli differs from M. galapagoensis Coineau and Schmidt, 1979 (found in coarse sediment in the lower littoral zone of several islands in the Galapagos Archipelago) in having a six-segmented antennule versus five; having two aesthetascs on terminal segment of antennule; having a much shorter endopodite on male pleopod 2 , without long and thin pointed process; having a broader uropod without curvature at the posterior end of the peduncle.

From M. salvati Coineau 1970 (living in coral sand, New Caledonia) by having a six-segmented antennule versus five; having 12 flagellum segments on the antenna versus 10; having a flat, slightly concave anterior margin of the cephalon versus a blunt rostrum; having five short setae at the tip of both halves in male pleopod 1 instead of four plus one long seta; having a curved posterior margin of pleopod 2 in female versus a straight margin.

From M. heimi Coineau 1970 (living in coral sand, New Caledonia) by having a six-segmented antennule versus five; having 12 flagellum segments on the antenna versus nine; having two aesthetascs on the 5th segment of the antennule versus one; having broad and bended inner claws on the pereiopod dactyli versus more slender and not hooked; having rounded tips of the pleopod 1 versus pointed ones.

From M. harrisi Spooner, 1958 (living in shell gravel off the coast of Southern England) by having a six-segmented antennule versus five; having 12 flagellum segments on the 
antenna versus ten; lacking an endopodal swelling on the peduncle of male pleopod 2; having a curved posterior margin of pleopod 2 in female versus a straight margin.

From M. monnioti Bocquet, 1970 (living in marine sands near Roscoff, Brittany, France) by having a wide and large uropod peduncle and short and thin rami versus the opposite combination.

From M. teissieri (Levi, 1950) living in coarse marine sand near Roscoff, Brittany, France, by having a six-segmented antennule versus five; having three pinnate setae on segment 3 of the mandible palp versus two; having a differently shaped peduncle of the uropod.

From M. marinus Chappuis and Delamare Debouteville, 1954 (living in sandy beaches in southern France) by having a pinnate setae among the simple setae on inner lobe of maxilla; having three spinulose setae on the posterior margin of endopodite of pleopod 3; having a broad peduncle segment in uropod 3.

From M. coineauae Galhano 1970 (living in littoral sands at the mouth of the river Douro, Portugal) by having a sixsegmented antennule versus five; having 12 segments on the antenna versus eight; having a pinnate setae among the simple setae on inner lobe of maxilla; having three spinulose setae on the posterior margin of endopodite of pleopod 3; having an inwardly curved posterior margin of the female pleopod 2 versus a straight margin.

In addition to these differences, there is the overall uniqueness of the squared corners of the male pleotelson, the lack of plumose setae on antennules and pereiopods, and the very robust and hooked inner unguis on the dactyli of the pereiopods.

\section{Discussion}

The antennule of Microcharon quilli consists of six segments, which is an unusual number, as it is in contrast with the observation (Stock 1977) that the fully marine Microcharon species have only five segments. The top of the antennule has a clear aesthetasc that is long and broad, but a smaller one is visible too. When checked with high magnification, this aesthetasc does not sprout from the top segment (as aesthetascs mostly occur in singles per segment), but comes from a small segment just below the top segment. It resembles the situation as shown in Lepidocharon priapus Galassi and Bruce, 2016, and Lepidocharon lizardensis Galassi and Bruce, 2016, displaying this configuration clearly in a SEM photograph. In Microcharon salvati, found in coralline white sands off New Caledonia, a situation is drawn in which two aesthetascs are placed, one apically and one subapically on a sort of pedestal; here the division into two segments is not visible. Upon re-examining the type specimen of M. herrerai, present in the Naturalis Biodiversity Center collection in Leiden, we found a similar situation as in M. quilli n. sp.: a long terminal aesthetasc, and a smaller one coming from the segment just below the terminal segment. This supports the probability that the antennule in full marine species consist of six segments, instead of five segments, which was the original diagnostic feature. Re-examining all known marine species may change the outcome of the number of segments significantly.

The morphological differences between the marine Microcharon species are rather subtle, as can be expected within genera that are almost exclusively found in the same type of microhabitat. They are often reported from places far apart from each other on the globe, and genetic connectivity between these populations is considered improbable. However, well-sorted, sandy sediments are present in a narrow zone along marine coasts (Fenchel 1987), and a continuum of species, of which most are undiscovered, might be in place. Therefore gradual, not abrupt, morphological differences are expected in the marine species of Microcharon, along a worldwide chain of these littoral coarse sand habitats. These are interrupted only by the Atlantic and Pacific Ocean that form truly deep basins. It is interesting in this respect to compare the distribution of the tiny worm-like asellote isopods of the genus Microcharon with that of the equally small amphipod wormshrimp Ingolfiella Hansen, 1903 (Vonk and Schram 2003; Vonk and Nijman 2006). Microcharon and Ingolfiella are usually found together in the shallow marine interstitial. However, where Microcharon has its main species radiation in continental groundwater (Coineau and Botosaneanu 1973), and but a few species present in the littoral fringe, the ingolfiellid amphipods occur mainly in marine environments (Rubal and Larsen 2012; Vonk and Jaume $2014 a, b)$ and also in deep oceanic seafloor habitats, with freshwater representatives in near-coastal continental groundwater (Ruffo and Vonk. 2001) and brackish water inhabitants in anchialine pools (Vonk and Iannilli 2013). As isopods are supposed to be much older (Carboniferous) than amphipods (Late Eocene), according to their fossil record (Schram 1986; Weitschat and Wichard 2010), the differences in distribution may reflect how the typical and vertically restricted habitat type of the shallow marine interstitial is shared by crustaceans with origins of different stages in the Earth's history in that particular ecological niche.

As was noticed earlier (Coineau 1970), it is likely that at least as many species are present in the marine realm as are currently found in riverbeds, freshwater wells, and springs. This sampling bias of collecting on land could potentially be causing overrepresentation of freshwater species.

The females in the samples hold two large eggs between large brood lamellae. The eggs are extremely large in relation to the body size of the female, and must form a hindrance in moving quickly through the interstices in a sandy bottom. Investment in a small number of eggs is predominantly an 
indication of a stable environment, with a controlled release of the young. Having so few eggs also summons a high fecundity in producing subsequent broods over time. It was observed in M. marinus that the duration from the appearance of two eggs until the release of one young - the other egg is expulsed prematurely from the marsupium - is about 2 months (Coineau 1971). The longevity, or lifespan, of Microcharon was rated around 2 years (Coineau 2000).

Acknowledgments We are grateful to Bert Hoeksema, Arjen Speksnijder (Naturalis Biodiversity Center), and Niels Schrieken (Anemoon Foundation) for organizing the St. Eustatius marine biodiversity expedition. We thank dive centre Scubaqua for providing good service, and Johan Stapel, Pepita Cannegieter, and Masru Spanner (CNSI staff) for actively facilitating research logistics on St. Eustatius. Two anonymous reviewers are very much thanked for their detailed and valuable comments.

Open Access This article is distributed under the terms of the Creative Commons Attribution 4.0 International License (http:// creativecommons.org/licenses/by/4.0/), which permits unrestricted use, distribution, and reproduction in any medium, provided you give appropriate credit to the original author(s) and the source, provide a link to the Creative Commons license, and indicate if changes were made.

\section{References}

Albuquerque EF, Boulanouar M, Coineau N (2014) First record of Janinella nom. n. (Crustacea: Isopoda: Microparasellidae) in the South Atlantic: revision of the genus and description of a new Brazilian species. J Nat Hist 48:1817-1823. doi:10.1080/00222933.2013.877996

Bocquet C (1970) Sur un nouveau Microparasellide marin des sables de Roscoff, Microcharon monnioti n. sp. (Isopodes Asellotes). Compt Rendus Hebd Séanc Acad Sci Paris, série D 271:85-87

Chappuis PA, Delamare Deboutteville C (1954) Recherches sur les Crustacés souterrains. 7. Les Isopodes psammiques de la Méditerranée. Arch Zool Exp Gén 91:103-138

Coineau N (1970) Isopodes interstitiels de Nouvelle-Calédonie. In: Salvat B (ed.)Expéditions Françaises sur les récifs coralliens de NouvelleCalédonie, Tome 4. Editions de la Fondation Singer-Polignac, Paris, pp 353-376

Coineau N (1971) Les Isopodes interstitiels documents sur leur écologie et leur biologie. Mém Mus Natl Hist Nat Ser A 64:1-170

Coineau N (1986) Isopoda: Asellota: Janiroidea. In: Botosaneanu L (ed) Stygofauna Mundi. Brill, Leiden, pp 465-472

Coineau N (2000) Adaptations to interstitial groundwater life. In: Wilkens H, Culver DC, Humphreys WF (eds), Ecosystems of the World 30, Subterranean Ecosystems. Elsevier,Amsterdam, pp. 189-210

Coineau N, Botosaneanu L (1973) Isopodes interstitiels de Cuba. In: Résultats des Expéditions Biospeologiques Cubano-Roumaines à Cuba. Academy of the Socialist Republic of Roumania, Bucarest, pp 191-222

Coineau N, Schmidt P (1979) Interstitielle Fauna von Galapagos 24. Microparasellidae (Isopoda, Asellota). Mikrofauna Meeresbodens 73:1-18

Coineau N, Boutin C, Artheau M (2013) Origin of the interstitial isopod Microcharon (Crustacea, Microparasellidae) from the western
Languedoc and the northern Pyrenees (France) with the description of two new species. Subterr Biol 10:1-16. doi:10.3897/subtbiol.10.4758

Fenchel T (1987) Ecology of Protozoa : the biology of free-living phagotrophic protists. Springer, Berlin. doi:10.1007/978-3-66225981-8, $197 \mathrm{pp}$

Galassi DMP, Bruce NL, Fiasca B, Dole-Olivier MJ (2016) A new family Lepidocharontidae with description of Lepidocharon gen. n., from the Great Barrier Reef, Australia, and redefinition of the Microparasellidae (Isopoda, Asellota). ZooKeys 594:11-50. doi: $10.3897 /$ zookeys.594.7539

Galhano MH (1970) Contribuicao para o conhecimento da fauna intersticial em Portugal. Publicacões do Instituto de Zoologia "Dr. Augusto Nobre" 110:9-206

Hoeksema BW (2016) Marine biodiversity survey of St. Eustatius, Dutch Caribbean, 2015. Naturalis Biodiversity Center, Leiden and ANEMOON Foundation, Bennebroek, 157 pp

Kensley B (1984) The Atlantic Barrier Reef Ecosystem at Carrie Bow Cay, Belize, III: New marine Isopoda. Smithson Contrib Mar Sci 24: $1-81$

Lévi C (1950) Duslenia teissieri nov. gen., n. sp. nouveau Parasellide des côtes de France. Arch Zool Exp Gén Notes Revue 87:42-47

Rubal M, Larsen K (2012) A new species of Ingolfiellidae (Peracarida, Amphipoda, Crustacea) from the Azores, Portugal. Helgol Mar Res 67:149. doi:10.1007/s10152-012-0311-6

Ruffo S, Vonk R (2001) Ingolfiella beatricis, new species (Amphipoda: Ingolfiellidae) from subterranean waters of Slovenia. J Crust Biol 21:484-491. doi:10.1651/0278-0372(2001)021[0484:IBNSAI]2.0. $\mathrm{CO} ; 2$

Schotte M (2007) Microcharon Karaman, 1934. In: Boyko CB, Bruce NL, Merrin KL, Ota Y, Poore GCB, Taiti S, Schotte M, Wilson GDF (eds) (2008 onwards) World Marine, Freshwater and Terrestrial Isopod Crustaceans database. Accessed through: World Register of Marine Species at http://www.marinespecies.org/aphia.php?p= taxdetails\&id=118373 on 2016-06-03

Schram FR (1986) Crustacea. Oxford University Press, New York, 606 pp

Spooner GM (1959) The occurrence of Microcharon in Plymouth offshore bottom fauna, with description of a new species. J Mar Biol Assoc UK 38:57-63

Stock JH (1977) Microparasellidae (Isopoda, Asellota) from Bonaire. Stud Fauna Curaçao Carib Is 168:69-91

Vonk R, Iannilli V (2013) A new Ingolfiellid (Crustacea, Amphipoda, Ingolfiellidae) from an anchialine pool on Abd al Kuri Island, Socotra Archipelago, Yemen. ZooKeys 302:1-12. doi:10.3897/zookeys.302.5261

Vonk R, Jaume D (2014a) Syntopy in rare marine interstitial crustaceans (Amphipoda, Ingolfiellidae) from small coral islands in the Molucca Sea, Indonesia. Mar Biodivers 44:163-172. doi:10.1007/s12526013-0193-0

Vonk R, Jaume D (2014b) Ingolfiella maldivensis sp. n. (Crustacea, Amphipoda, Ingolfiellidae) from coral reef sand off Magoodhoo island, Maldives. ZooKeys 449:69-79. doi:10.3897/zookeys.449.8544

Vonk R, Nijman V (2006) Sex ratio and sexual selection in wormshrimps (Crustacea, Amphipoda, Ingolfiellidea). Contrib Zool 75:189-194

Vonk R, Schram FR (2003) Ingolfiellidea (Crustacea, Malacostraca, Amphipoda): a phylogenetic and biogeographic analysis. Contrib Zool 72:39-72

Weitschat W, Wichard W (2010) Baltic amber. In: Penney D (ed) Biodiversity of fossils in amber from the major world deposits. Siri Scientific Press, Manchester, pp 80-115 